\title{
THE SOCIAL SIGNIFICANCE OF MR. NAZEER KHAN'S ARCHITECTURE
}

\author{
Spahic Omer \\ International Islamic University Malaysia \\ Malaysia \\ e-mail: spahico@yahoo.com
}

Received: May 25 ${ }^{\text {th }}$ 2015; Accepted: August $3^{\text {rd }} 2015$; Available Online: December $31^{\text {st }} 2015$

DOI: http://dx.doi.org/10.18860/jia.v3i4.2840

\begin{abstract}
This paper discusses the social significance of Mr. Nazeer Khan's architecture. The discussion revolves around the relationship between Mr. Nazeer Khan's architecture and Kerala Muslims' economic transformation, as well as Kerala state's inter-faith harmony. The study is not about delivering judgments concerning Mr. Nazeer Khan and his architectural exploits from a sheer perspective of architecture as a synthesis of art, science and technology, for such could significantly narrow at once our purpose and focus, and could divert our attention from some vital thrusts of the subject at hand. Rather, the study is about Mr. Nazeer Khan's architecture and Kerala's religious and socio-economic molds, and how they correlate with each other, the latter clearly dictating and shaping the former. It is only against this expansive and complex back-drop that Mr. Nazeer Khan's architecture could be properly observed and appreciated. A restricted and one-sided approach regardless of what it might be would in all likelihood lead to some incomplete, patchy and even unfair opinions and inferences. The paper is divided into six sections: (1) Introduction: why this study? (2) Who is Mr. Nazeer Khan? (3) Kerala Muslims' economic transformation; (4) Mr. Nazeer Khan's architecture and Kerala's inter-faith harmony; (5) Mr. Nazeer Khan's architecture: diversity in unity; (6) Conclusion. The content of this study is based, mainly, on the author's lengthy interviews with Mr. Nazeer Khan and many of his clients, as well as on the author's field visits to a majority of Mr. Nazeer Khan's completed and on-going projects. The interviews and field visits took place in 2013 and 2014.
\end{abstract}

Keywords: Nazeer Khan's architecture, Social significance, Kerala's interfaith harmony

\section{Introduction}

Such an architectural philosophy and style are to be viewed through the prism of the total way of life in which they were envisaged and wherein they were translated into a physical space. They were not to be viewed only through the lens of architecture as pure art, science and technology. Here, just as everywhere else, the world of architecture is to be expanded into the higher and more sophisticated realms of existence. Existence, on the other hand, is not to be distorted or narrowed down, so as to go well with the corporeal ingredients and dimensions of architecture only. The orb of architecture, it follows, is to become known as an ultimate spiritualized and "supernatural" orb, whereas the life phenomenon is not to be mechanized or rendered merely physical, inconsequential and perfunctory just on account of some of us falling short of penetrating into its complex meanings and secrets.

In other words, Mr. Nazeer Khan's architecture, far from being perfect or exemplary, is about a total life and a lifestyle which he ardently champions and lives. Neither he nor his architecture can be disconnected from the lives of Kerala people and their rising aspirations and dreams. If so, his architecture would become easily misconstrued, appearing to many people rather confusing, incomprehensible and even hollow and purposeless. Hence, by lots of people, professionals and ordinary folks alike, Mr. Nazeer Khan and his architecture are misunderstood. Arguably, more than anyone else in Kerala, he divides architectural opinions.

Mr. Nazeer Khan lives his architecture which, in turn, lives and exemplifies the lives of its numerous clients and users. They run through each other's veins. To Mr. Nazeer Khan, his architecture is a living organism with which he identifies himself and his own existence. So attached emotionally is he to his architecture that, surely, it is not an exaggeration to say that the structural and functional states of his buildings deeply influence his complete being and personality. By and large, they affect his psychological and emotional condition. He is happiest when his buildings are "happy"; he is saddest when his buildings are "sad". Having been for quite some time now aware of all these factors, 
it was easy for me to comprehend and come to terms with the merits of embarking on this type of study.

\section{Who is Mr. Nazeer Khan?}

Mr. Nazeer Khan is an Indian architect. He lives and works in the city of Calicut in Kerala, a state in the south-west region of India. He was born on May 30,1959 . Initially, his ancestors lived in the city of Kodungallur, a municipality in the Thrissur district of Kerala. It was his grandfather who migrated with his family from Kodungallur to Calicut.

Mr. Nazeer Khan and his family had humble beginnings, enjoying more than their fair share of hard times. His father was a modest timber merchant. When he was born, Mr. Nazeer Khan was perfectly healthy. However, when he reached the age of four years, his left hand became virtually paralyzed due to polio or infantile paralysis. Such a left hand condition lasted six years. But after six years, at the age of ten, Mr. Nazeer Khan's hand became miraculously cured and he started to live a normal childhood life.

During the period of left hand paralysis, which signifies a critical formative stage in every person's upbringing, Mr. Nazeer Khan lived under constant stress and fears. Just like every child, he had his big dreams and aspirations, but felt that he will eventually have to divest himself of most of them due to his precarious condition. However, when the illness was cured, his big dreams and ambitions returned, more compellingly and in more abundance. Mr. Nazeer Khan believes that his abounding artistic talent, which is brought to life and communicated mainly through the conduits of his hands from the depositories of his mind as well as heart, is a precious gift from God. With it, God, perhaps, wanted to reward him for the six years of hardship which he and his family patiently endured.

Having successfully completed his higher secondary education at the age of 19 years, Mr. Nazeer Khan proceeded to do a diploma in civil engineering. It took him two years to do so. It was here that he started displaying most effectively the abundance and depth of his architectural talent, polishing it and advancing it to higher levels. As a result, he was nicknamed "Mr. Accurate" by his peers owing to his not often witnessed precision, flair and ingenuity.

Following his completion of civil engineering diploma, Mr. Nazeer Khan, aged 21, joined the Indian civil service. For the next period of ten years as a civil servant, Mr. Nazeer Khan decided to practice civil engineering on a part-time basis as well. He did so for the first three years under the tutelage of Mr. Balakrishnan Nair, one of the leading civil engineers in Calicut. Next, for the remaining seven years, he worked with several other civil engineers in Calicut, also as a part-timer. It was this phase that proved most crucial. It was then that Mr. Nazeer Khan -- as well as his superiors and clients -came fully to the terms of his extraordinary talent and abilities, prompting Mr. Nazeer Khan to think about and plan for himself a much bigger and more challenging future.

In addition, such was a time when clear distinction between civil engineering and architecture, and between the term engineer and architect, was increasingly made in the Indian society. The two heretofore, generally, were referring to the same occupation, and were often used interchangeably. Mr. Nazeer Khan worked on the tasks which essentially were related to pure architecture, such as producing 3D drawings, building plans, designs, etc. Encouraged by his remarkable outputs and the positive feedbacks of his employers and clients, he, consequently, started to feel that he was born for architecture and that they existed for each other. And having accomplished a 10-year part-time job, as well as apprenticeship, in civil engineering and architecture under the guidance of some of the most prominent civil engineers and architects in Calicut, Mr. Nazeer Khan called it a day with his civil service career.

Although without required formal architecture education, he was ready to devote his full life to the profession. What is more, he was ready and willing to go solo as soon as possible. He was confident that his amazing talent, burning enthusiasm, lofty aspirations and accumulated experiences will be able to offset his lack of formal education. It was certainly risky, but Mr. Nazeer Khan was convinced that he had what it takes to succeed sooner or later in independent practice of architecture.

As a small digression, Mr. Nazeer Khan fondly recalls how during his part-time stints he always carried a booklet on whose pages he tried to express and deposit his blooming architectural ideas and convictions. Most of his drawings were spur-of-themoment, precipitate and unrefined. Nonetheless, he was more than happy to share them and his architectural thoughts that those drawings were supposed to characterize with as many individuals as possible from across the wide social spectrum of Kerala.

In so doing, he, admittedly, was a bit too zealous and relentless. Some people took him seriously, others paid no heed to the matter and every now and then even poked fun at him, and yet

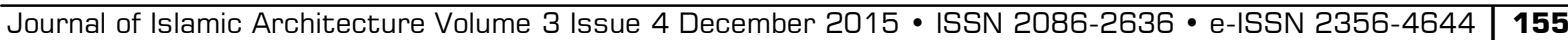


others regarded it as yet another display of $\mathrm{Mr}$. Nazeer Khan's augmented passion for the art and architecture disciplines. They even criticized him and his behavioral patterns somewhat for apparently going overboard, stopping almost at nothing to exhibit and prove his forte, and to achieve his set goals. In most cases, however, prolonged conversations and even debates normally ensued, involving individuals with different mindsets and from different socio-economic and religious backgrounds about what was available in the booklet and in Mr. Nazeer Khan's mind as well as heart.

However, little did the people realize that Mr. Nazeer Khan as early as then when he was just a young architecture enthusiast and fantasist, was a very shrewd man. $\mathrm{He}$, in point of fact, was conducting a test of public opinion concerning architecture in general, and concerning his own architectural notions and proclivities in particular. He was testing people's perceptions as well as preferences with regard to the realms of art and architecture. He was searching for a universal taste, so to speak, among his people, which he later when given a chance could attend to and try to satiate.

As a matter of fact, Mr. Nazeer Khan's transition from part-time to solo practice of architecture was a gradual one. He firstly fostered an architectural partnership with Mr. Muhammad P.K., his classmate and close friend when he studied for his diploma in civil engineering. The partnership lasted six years. They then parted on the best of terms. They each planned to grow more autonomously, freely charting their own respective career paths. Mr. Muhammad P.K. went on to become a contractor, while Mr. Nazeer Khan finally embarked on practicing architecture as a full-time profession and running it as a one-man enterprise. Mr. Muhammad P.K.'s first work as a contractor was part of a project that belonged to Mr. Nazeer Khan.

After that, Mr. Nazeer Khan rapidly grew as an architect, establishing himself as one of the most influential, talked-about and sought-after architects in Kerala. At the moment, his office has 15 supporting staff members. He also has ten site supervisors and four consultants: one for plumbing, one for electrical and two for structural engineering. The two structural engineering consultants are university professors from the National Institute of Engineering Technology (NIET) in Calicut.

$\mathrm{He}$ at any given time deals with at least 50 contractors, organizations and individuals that are contracted with him for the construction of his buildings. Some work only for him. Mr. Nazeer Khan estimates that there is a workforce of at least 2,500 people -- be they his assistants, site supervisors, consultants, contractors, building materials and furniture manufacturers and suppliers in India and abroad, etc. -- behind the construction of his current architectural projects with tens of millions of US dollars in circulation and changing hands. In as far as Indonesia, for example, there are two furniture companies that operate principally for him. The impact of Mr. Nazeer Khan's establishment primarily on Kerala's economy, and on some others like in Indonesia and $\mathrm{UAE}$, is very strong and palpable.

So far, Mr. Nazeer Khan has designed more than 1,000 houses, most of which are huge and palatial. He also designed 25 mosques, two Muslim shrines, two Hindu temples, 25 shopping centers, 10 churches, 10 monasteries for Christian priests, 10 schools, one house for elderly people, one school for bishops, five community halls, two orphanages, one spiritual guidance center for Hindus, three hospitals, eight hotels and six convents for nuns. Moreover, he designed the interiors of 10 exclusive restaurants and about 100 gold, jewelry, furniture, textile, floral, etc., showrooms.

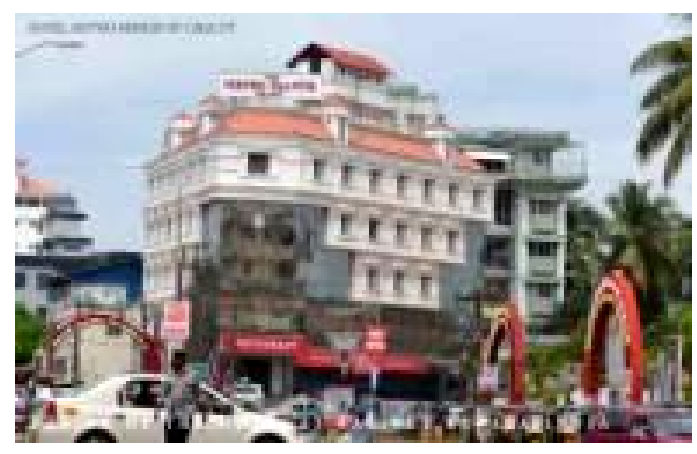

Figure 1. Hotel Metro Manor in Calicut, Kerala.

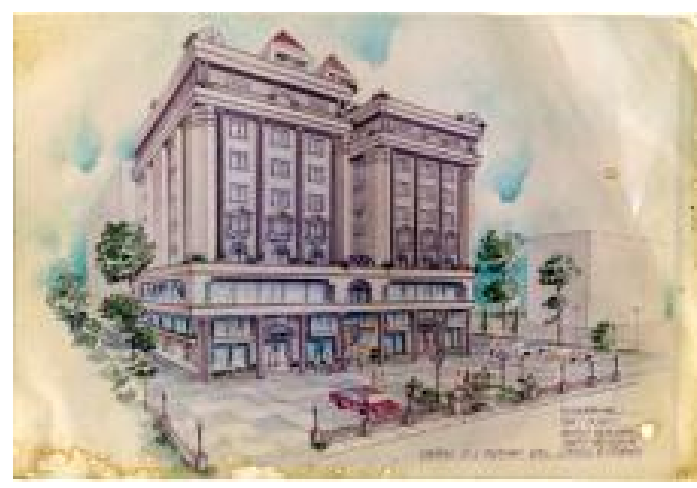

Figure 2. A proposed hotel complex in Thalassery, a commercial town on the Malabar Coast in the Kannur district, Kerala.

This means that Mr. Nazeer Khan handles a couple of hundreds of projects at any given time. 
Yet, he remembers even the smallest details pertaining to each and every aspect of his projects. He can easily pinpoint any mistake committed by anybody in the process of construction, although he is not physically always present. It is truly astonishing how he ensures that nobody underperforms or commits and runs away with any constructional deficiencies or deviations from his original ideas and designs.

Besides, Mr. Nazeer Khan is an astute businessman as well. Among other things, he owns an estate of 300 acres of coffee and orange plantations with more than 100 local workers. Its worth is difficult to estimate, but it perhaps is in the range of a few millions of US dollars. Anyhow, Mr. Nazeer Khan rarely talks about it, among other things due to his persona which oozes humility and unassuming nature. The estate's location is in the Thirunelli area, in Wayanard district in the northeast of Kerala. Not far from it, Thirunelli Temple, one of the most ancient Hindu temples dedicated to Lord Vishnu, is sited.

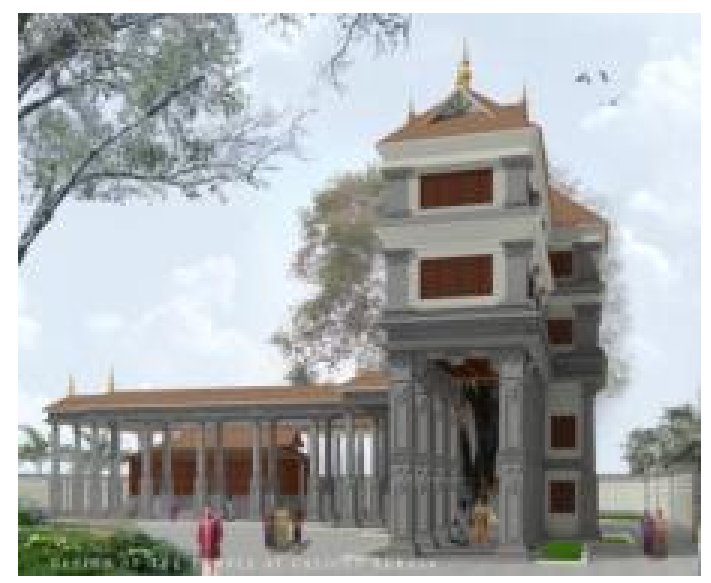

Figure 3. A Hindu temple in Calicut, Kerala.

Admittedly, the estate's economic potential is far from being fully exploited because to Mr. Nazeer Khan, that pursuit always played second fiddle to his architectural work and passion. The estate is about three hour drive from the city of Calicut and Mr. Nazeer Khan's house and place of work. He manages to visit it only once in three or four months. The estate has a manager who manages it on Mr. Nazeer Khan's behalf. Thus, Mr. Nazeer Khan admits that he will always have more of everything, except time. He says he will never have enough of it to do what he wants, needs and what other people would like him to do for them.

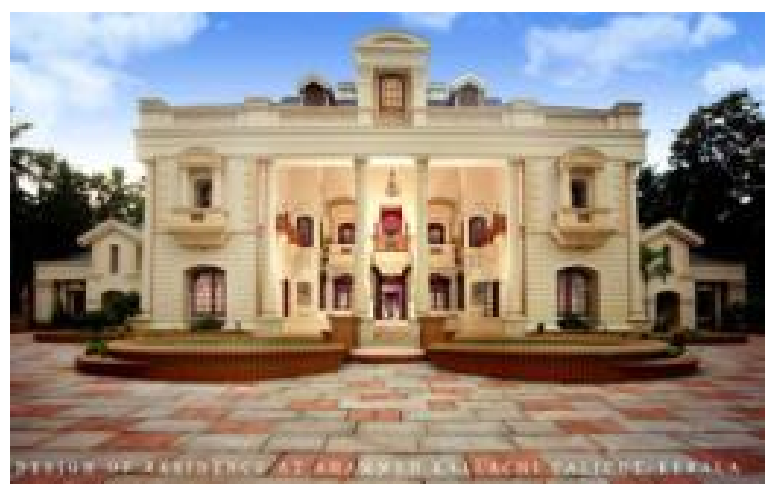

Figure 4. The house of Mr. Ahammed in Kallachi, Calicut, Kerala.

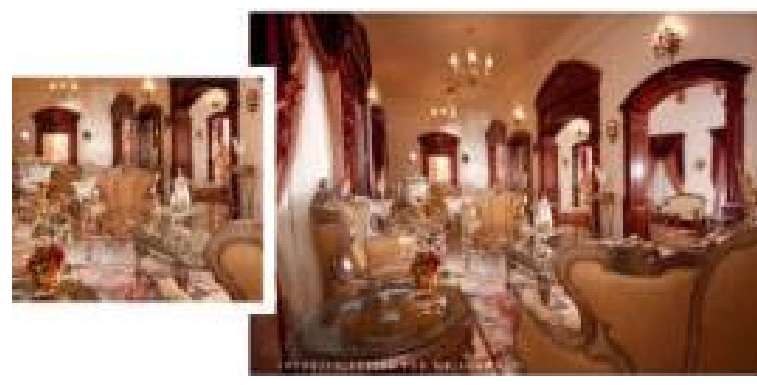

Figure 5. The opulent and tasteful interior of the house of Mr. Ahammed in Kallachi, Calicut, Kerala.

\section{Kerala Muslims’ Economic Transformation}

From 1972 to 1983, there occurred a phenomenon which came to be known as the "Gulf Boom", in consequence of which the Kerala Gulf diaspora was created. The Kerala Gulf diaspora refers to the people of Kerala living in the Middle Eastern Arab states of the Persian Gulf. In 2008, they numbered more than 2.5 million. Since the commencement of the Boom, the mass migration of a large number of people from Kerala was set in motion. "Largely consisting of the migration of Malayalis, the dominant indigenous ethnic group in Kerala, the movement of many migrant workers from Kerala to the Gulf Countries continues to the present day, although in smaller numbers after the 2008 international financial crisis began to affect the Gulf region. This initial wave of migration is usually referred to as the Kerala Gulf Boom. The Kerala migrants are usually laborers and low-skilled workers."[1]

In 2008, the Keralite population in the Gulf, which numbered more than 2.5 million, sent home a sum of around 6.81 billion USD, which was more than $15.13 \%$ of the total remittance to India in 2008. In 2013, the remittance was almost ten billion USD[2]. 
Since a substantial population survives on remittances, Kerala's economy is what the people used to term "Money Order Economy". Earlier, they used to send it by Money Orders. In the present day, the remittances are made by inter-bank or intrabank electronic transfers [1][2].

The following examples, too, show to what extant remittances constitute a key source of income for Kerala's economy. “In 2003 for instance, remittances were 1.74 times the revenue receipts of the state, seven times the transfers to the state from the Central Government, 1.8 times the annual expenditure of the Kerala Government, and 15 to 18 times the size of foreign exchange earned from the export of cashew and marine products."[2] Although the majority of Gulf migrants were from the working and the lower-middle classes, many still managed to climb the ladder of success and become very rich and successful. Consequently, gulf migrants gradually gained local fame and social status. A myth of a "Gulf man" was created and puffed up. The notion of "Gulf Dream" became a national craze. It was on everyone's lips, almost everyone's ultimate ambition.

As to the basic demographic characteristics of the Kerala Gulf diaspora and its remittances, according to Malika B. Mistry, "Muslims constituted $44.3 \%$ of the emigrants from Kerala in 2011, while Hindus formed $36.4 \%$. Muslims have been leading all through the recent years. While there were 60 emigrants per 100 households among Muslims and 30 among the Christians, the Hindus have only 19 emigrants per 100 households[2]." As a consequence, "on an average, a Muslim household received Rs. 135,111 (2, 257 USD) as remittances in a 12-month period. A Christian household, on the other hand, received not even half of what a Muslim household received (Rs. 59,175 or 988 USD). In case of the Hindus, the average remittance a household received is only about one-fourth of what a Muslim household received (Rs. 38,489 or 642 USD)[2]."

Malika B. Mistry continues with reference to the impact of the Gulf Boom on the life-style of Kerala emigrant Muslims, singling out the subject of housing in the state. "Households with an emigrant or return emigrant tend to possess better quality houses than those without an emigrant. The proportion of households possessing 'luxurious' or 'very good' houses shows a steady increase with the number of non-resident Keralites (NRKs) in the household, and is $24.2 \%$ for households without an NRK and $41.3 \%$ for households with one NRK, $50.3 \%$ for households with two NRKs and $65.2 \%$ for households with more than two NRKs [3]."

As was expected, with the influx of wealth into the Kerala state, and with an increase in the number of wealthy households, demand for unique housing styles which will mirror and testify about the people's successes and their newly acquired status, dramatically increased. This was predictable on account of houses being so essential to human nature and existence that they define our identities and life stories. They are the symbols of our being, our aspirations and our life triumphs. They are thus microcosms of human cultures and civilizations. They are likewise equivalent to institutions, establishments, signs, credentials and testimonies.

Accordingly, many Kerala architects stepped up the supply of what was ever more demanded, in turn setting off a stiff competition. One of them was Mr. Nazeer Khan. However, for rising to the top, there was only one rout that amalgamated each of professional excellence, total dedication and clients' satisfaction. Mr. Nazeer Khan was able to accomplish all of them. He surely had what it takes to rapidly emerge as a foremost Kerala architect sought after as much for designing private houses as for institutional buildings, and as much by the Kerala Gulf diaspora as by those who lived and made fortune inside Kerala and beyond in India.

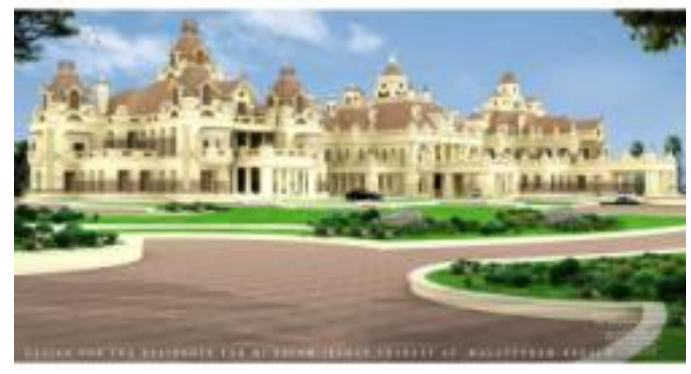

Figure 6. The house of Mr. Salam Irshad Shareef in Malappuram, Kerala.

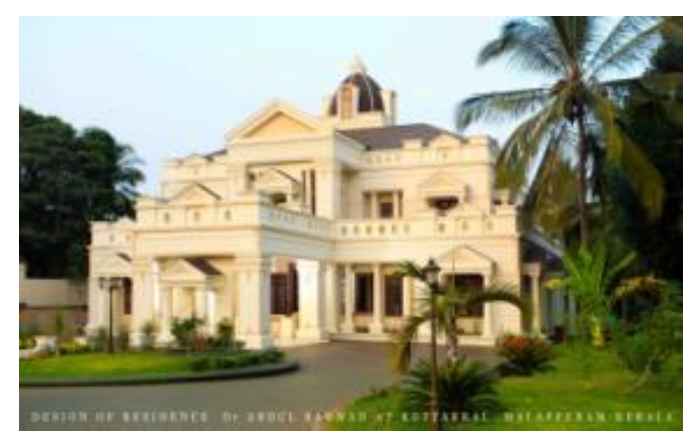

Figure 7. The house of Dr. Abdul Rahman in Kottakkal, Malappuram, Kerala.

It is true that the relative majority of Mr. Nazeer Khan's clients comprises the members of the Gulf diaspora, however, a great many clients are still 
locals. The latter comes from different strata of the Kerala community. They are numerous businessmen from diverse business fields, educationists, medical doctors, engineers, politicians (one is a member of Kerala Legislative Assembly), religious leaders, university professors, lawyers, police officers and military personnel. Many others plan or just pine for engaging Mr. Nazeer Khan as the architect of their future houses.

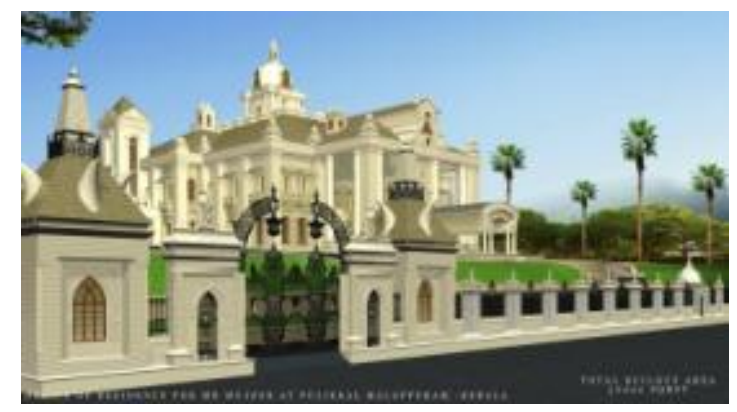

Figure 8. The house of Mr. Mujeeb in Pulikkal, Malappuram, Kerala.

When spoken to, all the clients are unanimous in one thing: they wanted to build dream houses which were meant to denote a pinnacle of their successful life struggles and professional careers. They wanted houses which will at once typify their achievements and dreams, and promote as well as facilitate living them to the fullest and till the very end. They wanted something special, ingenious and serviceable. In Mr. Nazeer Khan, an inspiring character for his peers as well as the future generations, they found a person whom they could trust and whom they could entrust with building their houses and so, their dreams. Hence, Mr. Nazeer Khan is often described as a "Builder of dreams".

Indeed, the judgments concerning many aspects of Mr. Nazeer Khan's architecture are subjective, often charged with certain emotions, but what undoubtedly singles him out and makes him stand head and shoulders above the rest is the utter and unreserved satisfaction of all clients of his. They are happy with Mr. Nazeer Khan as a person and professional, and with what he conceives and delivers to the people. As a result, his professional relationships with his clients practically always turn into close and everlasting friendships. This is in accordance with the principle that just as architecture is integral to life, architects likewise are integral to society. There is no detachment or rift between them. They derive their respective strengths from each other's domains and jurisdictions. They are inter-reliant. Undeniably, architecture is both life and society, symbolizing, framing and facilitating them.

Accordingly, all Mr. Nazeer Khan's clients believe that their houses are good value-for-money and that all their expectations have been duly met, something that arguably is most important in the realm of architecture. Indeed, an architecture that results from a process, relationship and an environment where every actively involved party is content and pleased, deserves praise, notwithstanding what some people may say on the basis of certain criteria and standards about which the clients, the most important stakeholders in architecture, neither care nor deem consequential.

It is noteworthy, furthermore, that as far as Mr. Nazeer Khan is concerned, this unqualified satisfaction and trust of his clients, as a result of long and professionally executed architectural processes, intimate relationships and favorable atmospheres, applies not only to private houses, but also to institutional buildings where money is always an issue and where fulfilling some specific communal cultural or religious specifications can also be very challenging. Which is why Mr. Nazeer Khan could be dubbed an architect for all seasons and for all budgets, able to deliver whatever is asked from him both at individual and institutional levels.

Lastly, since many of Mr. Nazeer Khan's clients had humble beginnings depending on nothing but their own sweat and toil while trying to succeed and leave a mark in the increasingly competitive business world, their beautiful and imposing houses radiate inspiring messages to those who want to follow in their footsteps that everything reasonable is possible if approached with persistence, hard work, patience and right attitude, and that every dream is attainable if dreamed, planned and managed aright. It is not only his clients and their life legacies, but also Mr. Nazeer Khan himself and his own legacy, that can attest to this very truth. Hence, Mr. Nazeer Khan's architecture is a testimony and proof. It conducts a silent campaign, so to speak, for a life vision and purpose. It invites the people as much to enjoy its artistic and architectural splendors as to appreciate the life philosophy and values that underpin it. It invites the people to spiritually connect to it and its multi-tiered world. It invites them to unleash their potentials and try to see and enjoy the world in its truest colors.

\section{Mr. Nazeer Khan's Architecture and Kerala's Inter-faith Harmony}

Islam entered India almost in the life-time of the Prophet Muhammad (pbuh). Generally, it is thought that it came into India by way of invasion by 
Muhammad b. Qasim, a young general sent by Yusuf b. Hajjaj, the governor of Iraq during the Umayyad period in the later part of the 7th century CE. But this is not true. Islam entered India initially through Kerala on the west coast through the Arab traders in a peaceful manner[4]. "The region called Malabar in Kerala is an Indianised form of ma'bar which in Arabic means passage. Since the Arab traders passed through that region often it came to be known by that name. The Arabs, in fact, had been trading since pre-Islamic days and then embraced Islam after the Prophet Muhammad (pbuh) began preaching. They married the local women in Kerala and their offspring spread in different parts of that region. Also, later they were accompanied by Sufi sheikhs who converted many local people, mainly from lower classes, to Islam. Thus, this was the real entry point of Islam into India[4]."

Kerala is a multi-religious state, somewhat more than many other Indian states. According to 2001 Census of India figures, Hindus form the largest religious community constituting $56.2 \%$, followed by Muslims $24.7 \%$, Christians 19\%, and the remaining $0.1 \%$ follows other religions[5]. In comparison with most of India, Kerala experiences relatively little sectarianism. It in fact serves as a symbol of interfaith harmony often given as an example for others to emulate. Siddiq Hassan 'Abdullah, the amir of the Kerala unit of the Jama'at-i-Islami and a well-known Arabic scholar, explains some of the main causes for such a situation: "The Muslims in north India and the Muslims here in Kerala have had a vastly different historical experience. India's first contact with Islam took place in Kerala. Even prior to Islam, Kerala had close trade links with the Arab world. Arab ships would regularly visit Kerala ports and some Arabs even settled here. After the rise of Islam, these links became stronger. Large numbers of Arab merchants settled here, and they were warmly welcomed by the local Hindu kings, because they played a vital role in the local economy. Islam thus came to Kerala through traders, and not through conquerors, unlike in much of the rest of India. This is why relations between Muslims and Hindus in Kerala have always been generally cordial, unlike in much of the north. Because of the close relations between Hindus and Muslims here, Kerala evolved a shared culture, and so Muslims are not seen as strangers. Rather, they are recognized as fellow Malayalis and are well integrated into the local society. Muslims, Christians and Hindus in Kerala share a broadly common culture and speak the same language. You don't have 'Hindu' restaurants and 'Muslim' restaurants here, as you do in some parts of north India. Because of the long history of communal amity in Kerala, it has been much easier for Muslims to organize and work for the advancement of the community here. The situation in the north has been very different. In the north, the trauma of the Partition still lingers on, which has had a terrible impact on inter-communal relations and has generated tremendous insecurity among the Muslims there. Here in Kerala we were spared the horrors of the Partition, because of which we have been able to focus our energies on constructive community development work, unlike in much of the north. In the north, large numbers of educated and prosperous Muslims migrated to Pakistan, leaving the poor behind. Almost no migration occurred in Kerala in the wake of the Partition[6]."

According to Hussain Randathani, "the egalitarian ideals of Islam, the existence of Arab colonies, the social and economic systems in the region and the positive attitude of the native rulers were the main factors which made Malabar a fertile region for Islam[7]." However, "except the reign of the Arakkal Ali Rajas of the north and a short interlude of the Mysorean over lordship, practically there was no Muslim rule in Malabar[7]." This, however, does not mean that the Muslims did not get total official freedom to practice and propagate their religion. They rather were accorded all the needed help and facilities to do so. In addition, they, their religion and culture were held in high regard by the region's Hindu sovereigns. The religious, economic and social personal and institutional lives of the Muslims thus always flourished, something that could not escape the attention of impartial and fair-minded travelers, historians and writers throughout the region's rich history[7].

In order to reciprocate this honest and amicable treatment, the Muslims of Kerala (historical Malabar is part of it) made the spread of Islam in the land a peaceful one, in conformity with the universal and peaceful message of Islam and without any imperialistic designs. The missionaries of Islam, be they merchants, mystics, scholars or just ordinary people, adopted a policy of sulh $i \mathrm{kul}$ (peace for all). They respected the ancient customs and obeyed the rulers. They were agents of harmony, unity and prosperity, and were the people of peace.

Moreover, upon converting to Islam, many neoconverts, a bulk of which belonged to Hindu low castes, were reasonably tolerated to retain some folk traditions of theirs, giving them a place in the Islamic core of the Kerala society[7]. As a result, there was little in the end to distinguish between the two communities in the fashion, culinary and wedding traditions, and in many other social life customs and preferences. Several Muslim festivals 
significantly resembled certain Hindu festivals. Some prominent Muslim saints became saints for many Hindus as well, on account of them having set the standards and examples of inter-faith peaceful coexistence, and having led by example. Their shrines or dargahs were the target of seasonal visits by both Muslims and Hindus, radiating endless barakah or blessings for all [7].

The Hindu-Muslim cultural confluence in Kerala is also evident in the fields of art and architecture. Hussain Randathani writes that Kerala traditional mosque architecture resembles Hindu temple architecture in all respects except the interior. This was so because in the beginning friendly Hindu kings allowed some temples to be converted into mosques, which was done with the least modifications to suit modest Muslim requirements. But if new mosques were built, the fact remains that they, in the main, were done by Hindu carpenters and masons who could not but follow Hindu temple style. The practice of providing grants by Hindu rulers for erecting mosques was common; as was the practice of erecting temples and mosques side by side[8].

Understandably, every Muslim and Hindu in Kerala is proud of this predominant cultural ethos in the state, trying to contribute their shares for sustaining it. Mr. Nazeer Khan is no exception and his architecture attests to it.

To begin with, Mr. Nazeer Khan reveals his belief in the myth according to which a native king, called Cheraman Perumal, traveled to Makkah and embraced Islam at the feet of the Prophet Muhammad (pbuh)[9]. After remaining in Arabia for a few years, the ruler intended to return home, but on the way died in Yemen. On his trip, a small delegation of local Malabar noblemen accompanied the king and also like their king, accepted Islam. Mr. Nazeer Khan proudly divulges that he accepts as true that a member of the king's delegation was one of his ancestors on his mother's side. Apart from the fact that these highly disputable claims serve to him as a source of inner pride, happiness and motivation, Mr. Nazeer Khan also interprets them to the effect that he thus was given an extra obligation to play a role in promoting and preserving the unique soul and character of the Kerala society as they were fashioned and upheld by the Kerala predecessors through ages.

As a further evidence for his penchant for propagating and practicing inter-faith tolerance and harmony, five of Mr. Nazeer Khan's office workers are Hindus, one is Christian, and nine are Muslims. Of his four consultants, furthermore, three are Hindus and one is Christian. Of his ten site supervisors, six are Muslims and four Hindus. Nor does he shy away from designing, apart from mosques and Muslim shrines, Hindu temples, churches and other Hindu and Christian institutional religious buildings. His clients for private houses, too, come from diverse religious backgrounds, even though the Muslims comprise the majority. When selecting contractors for building his projects, all Mr. Nazeer Khan's criteria revolve around excellence, professionalism and honesty. They are as good as religion-blind.

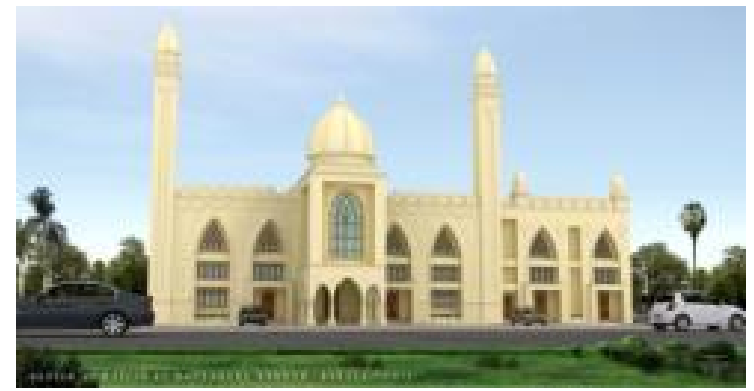

Figure 8. A proposed mosque in Mattanurl Kannur, Kerala.

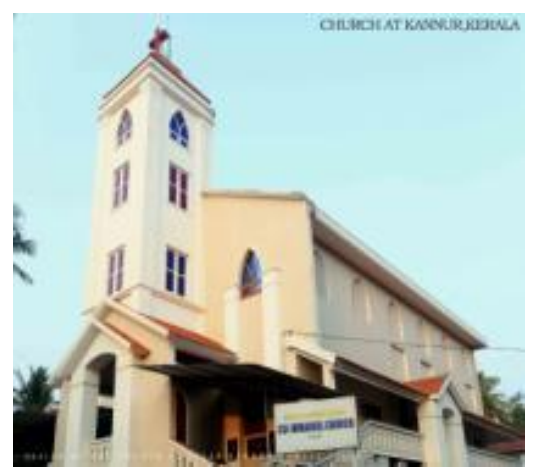

Figure 9. CSI Immanuel church in Talap, Kannur, Kerala.

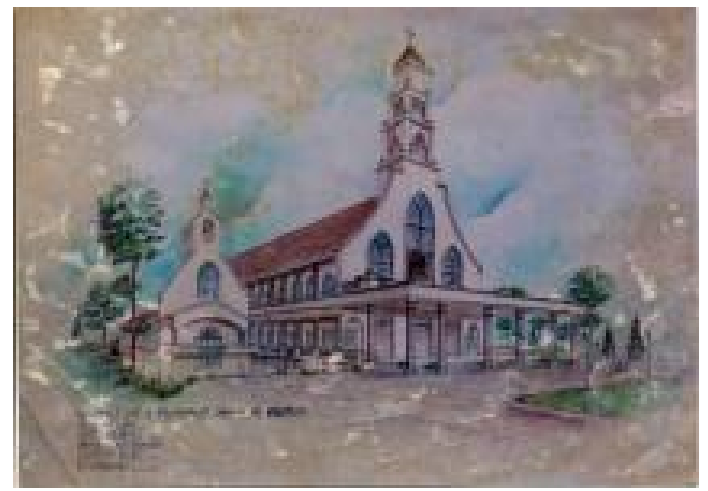

Figure 10. A proposed church in Pulpally, Kerala.

It was due to this inter-faith understanding and harmony predilection that Mr. Nazeer Khan is highly respected and wanted by his potential clients, Muslims and non-Muslims alike, and for both 
individual and institutional buildings. When talked to, it is thus not startling that all his non-Muslim clients all at once and completely approved of him and what and how he does. It was them who needed an architect, and they went for Mr. Nazeer Khan owing to his wide-spread reputation and legacy. They knew that he, as his record shows, always lives up to the mark and capably fulfils given tasks. Mr. Nazeer Khan never tries to impose himself on a client. Rather, he lets his buildings, as well as past and current clients, do the talking. They are his ambassadors and promoters. And he knows that such is the most effective promotion and marketing strategy. It, at the same time, is the cheapest and most abiding.

What brings closer and then bonds Mr. Nazeer Khan with his non-Muslim clients is a set of universally acceptable personal and professional values which are cherished by everyone irrespective of their religious beliefs and affiliations. Mr. Nazeer Khan champions those values more than anything else. Next, he makes his buildings personify and reflect those and other art and architecture related values and meanings, which is the language most people easily comprehend. It is about identifying and delving into what brings people together, not what separates them. It is about accentuating similarities, which are many, and dispensing with divisive differences, which, conversely, are few and often inflated and feigned. It is about celebrating universal affection for aesthetics, elation, passion, well-being, gratification, belongingness, equilibrium and good judgment. It is, finally, about helping a client -- or clients -- celebrate life in the most fundamental and intrinsic way.

Mr. Nazeer Khan's architecture, it goes without saying, is comprehensive and global, rather than specific and local. Its functions range from micro individual and family concerns to macro issues and fads in relation to the ubiquitous life phenomenon. One of his residential buildings near Kottakal in Kerala partially resembles each of a church, mosque and a temple at the same time[10]. The building, in many ways, typifies Mr. Nazeer Khan and his interreligious outlook translated artistically and architecturally into the physical world. Since architecture to Mr. Nazeer Khan signifies more than just a profession, he does not charge for designing mosques, temples and churches. For other religious institutional buildings, he charges only nominal fees. For private houses alone, he charges full fees.

Because of this platform, Mr. Nazeer Khan effortlessly settles those issues which are purely and instructively religious and which are to be integrated into buildings' designs and plans. Normally, he goes about doing that in two ways. First, he talks to clients as well as religious experts so as to be enlightened and guided in his work. Or he simply learns and discovers himself and then draws on his own knowledge and experiences while incorporating required religious specifications into his designs, while in the end seeking final endorsements from the clients, or their religious leaders, for his proposed design solutions. When designing Hindu and Christian houses and religious buildings, Mr. Nazeer Khan usually provides the clients with general building designs and plans. He provides detailed building frameworks. Most of interior design and decorative systems, however, due to their intricacies, precisions and numerous religious implications, he delegates to others who are more profoundly identifiable with them, to perform. That involves, for example, provision of crosses, statues, religious images and inscriptions, etc.

An example here is the house that belongs to Mr. Rajesh Jose, a Christian. The owner wanted his house to have an altar. He wanted the best location for it to enable it to function as a sacred way to call spiritual energies into home, and to reinforce the intentions of the house dwellers to invite more peace, serenity, and love into their spaces. Eventually, the ground floor of his house was planned in such a way that it had a sort of a central nave extending from the main entrance to the virtual end of the house where, raised above the level of the floor, an altar was positioned - an arrangement reminiscent of that found in Roman basilicas. The altar's location was ideal, greatly impressing the owner. When asked who guided Mr. Nazeer Khan concerning the matter, Mr. Rajesh Jose just replied: "Nobody; he knows all that."

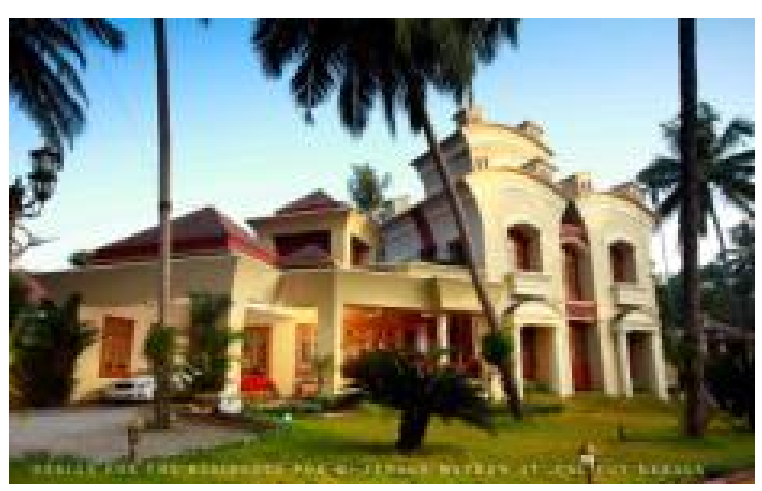

Figure 11. The house of Mr. Jenson Mathew in Calicut, Kerala.

Mr. Nazeer Khan proudly recalls that once the committee of a school for bishops, which they wanted to build, discussed with him their needs and the institution's overall specifications. So inspired and at ease was he then that he produced all initial 
sketches instantly, during the very conversation. He is thus fond of saying about that occurrence that it took him only "ten minutes" to do the job. A committee member then remarked: "You are a special divine gift. That's why we wanted you for this assignment." The school included a chapel and other educational and Christian religious facilities, as earlier specified by the committee.

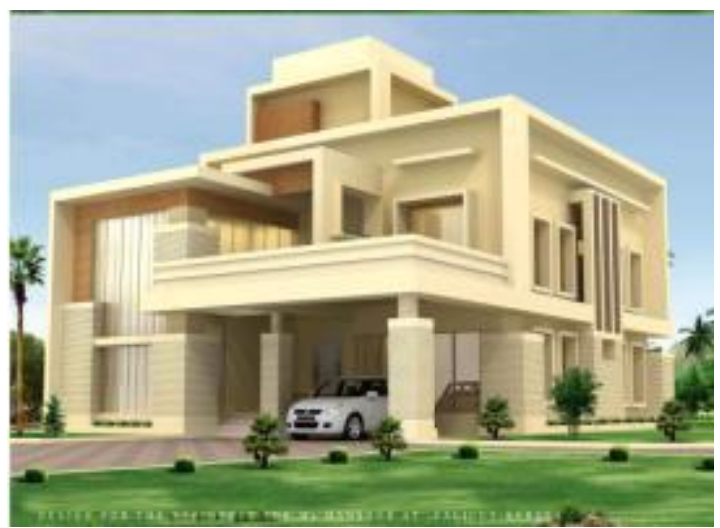

Figure 12. The house of Mr. Mansoor in Calicut, Kerala.

Moreover, when designing and planning a Hindu house - like what he did for his Hindu friend V. Rajeendranath -- Mr. Nazeer Khan is fully aware of the importance of incorporating a shrine into its plan and design, although such is entirely up to the clients whether they want it or not. He normally discusses the matter with his clients, and if needed, with a relevant religious person, but always seems very self-assured and up to date concerning it. Parenthetically, the heart of a religious Hindu house is its shrine: "the sacred space set apart for honoring and worshiping the gods. While a particularly devout Hindu may visit a temple every day, others go there only to request a favor of the deity, to fulfill specific vows, or on festival days. The pujas (prayer rituals as a means of honoring the gods or goddesses, whose presence in the home is believed to protect the family and to engender good fortune) that take place in the household shrine are the foundation of all family actions and decisions. Temple worship requires the intervention of a priest, but in the home the contact between devotee and deity is direct. The size and decoration of a household shrine do not matter. The shrine may be large and impressive, an entire room or a beautifully designed edifice, or it may be simply a tiny niche, or even just a row of religious prints pasted on a wall[11]."

Additionally, some Hindu clients might be keen to incorporate elements of vastu shastra or science of construction into their house designs as well.
Vastu shastra denotes both an ancient and sacred Hindu body of knowledge revealing the connection between humans, the laws of nature and the dwellings humans inhabit. While not claiming to be an expert in it, Mr. Nazeer Khan still acknowledges that he has a fair amount of knowledge about it, and if necessary, will be ready to explore it even further with his potential clients. So far, however, he had no Hindu client who insisted on the strict observance of vastu shastra precepts and a building's design based on directional alignments.

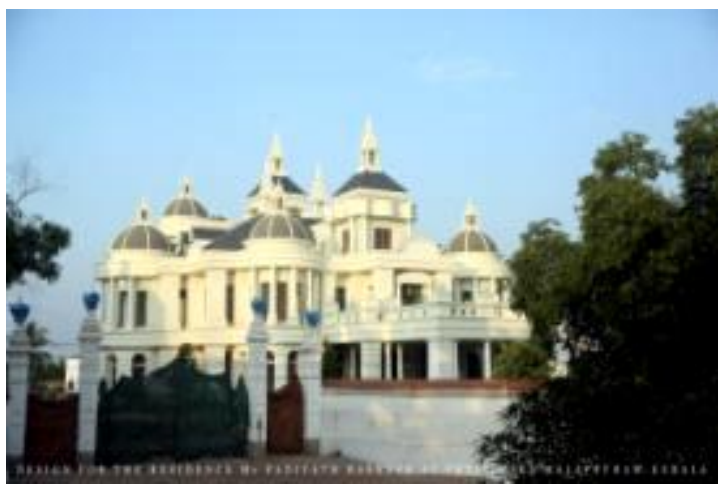

Figure 13. The house of Mr. Bashir Padiyath in Vettichira, Malappuram, Kerala.

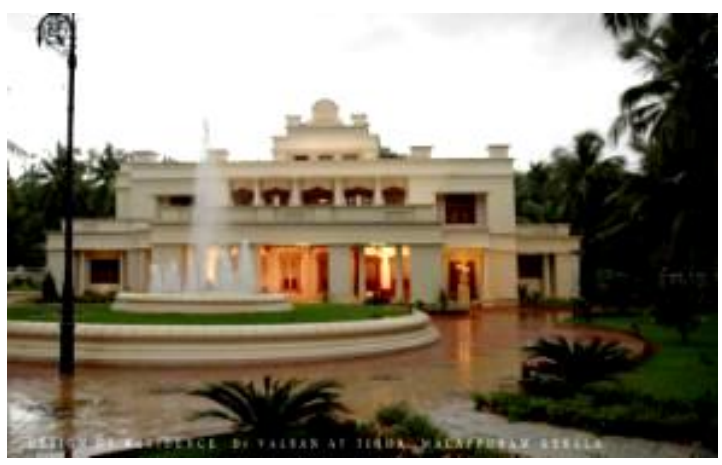

Figure 14. The house of Mr. Valsan in Tirur, Malappuram, Kerala.

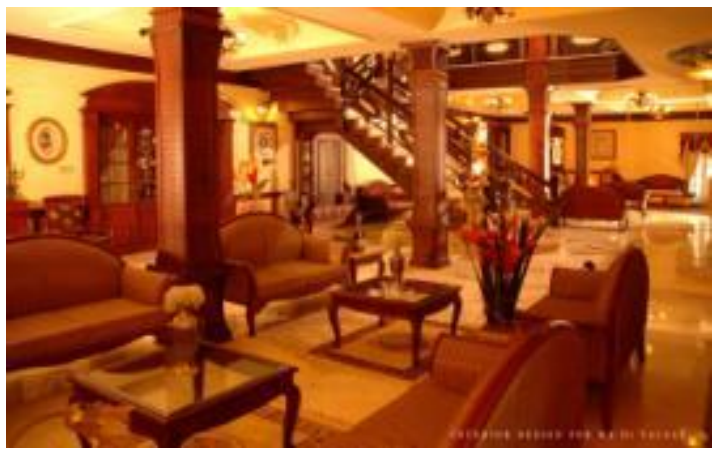

Figure 15. The sumptuous interior of the house of Mr. Valsan in Tirur, Malappuram, Kerala 
When designing Muslim houses, Mr. Nazeer Khan, being a Muslim himself, instinctively observes especially three things. First, a place for daily prayers and other Islamic rituals (musalla) is to be designated, whose size and design are subject to the size of a house and the availability of spaces in it. Second, decoration must not contain statues and human being images. The focus is on Islamic spiritual calligraphy, abstract geometric patterns, floral elements and natural landscapes. Third, the privacy concerns of a house's household must be acknowledged and its protection duly facilitated. As a result, for example, a guest or visitor room with all its facilities is always placed near the main entrance so as not to affect and disturb the normal life flow inside a house.

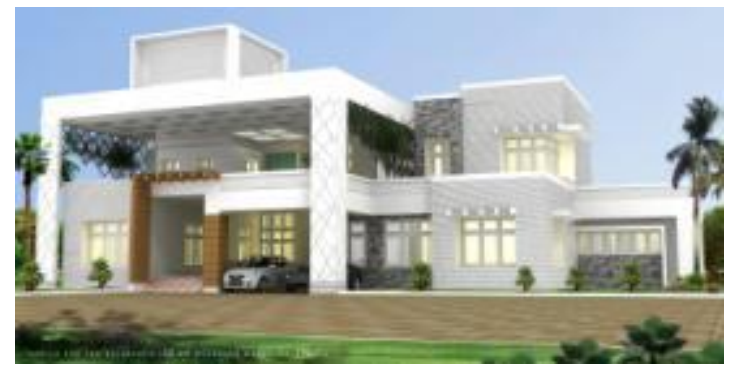

Figure 16. The house of Mr. Musthafa in Wayanad, Kerala.

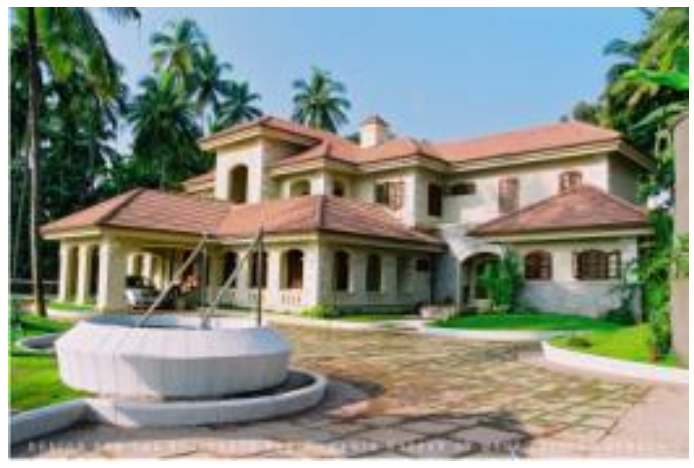

Figure 17. The house of Mr. Zahir Hassan in Mahi, Calicut, Kerala.

Sometimes a guest room is planned and executed in such a way that it seems as though it forms an annex or an auxiliary building situated near a main one. It may or may not have a direct access to the main body of a house from inside. If it does, the access is gradual and never abrupt, and always leads to the most "public" areas of a house. If it does not, that means that the room is accorded its own entrance from outside and the guests and visitors must use the main entrance only if they want to enter the house proper. Therefore, Mr. Nazeer Khan's Muslim houses have at least a double inner circulation and the organization of inner spaces and their functioning are multi-leveled and somewhat hierarchical.

When he is commissioned to design Muslim institutional buildings, Mr. Nazeer Khan applies his typical community-oriented approach and wants to attain his typical community-oriented results. He wants those buildings to function as centers of, and for, societal peaceful and harmonious life, among the Muslims and between the Muslims and others, and he does his best to ensure that his design ideas and solutions make a contribution to achieving that noble goal.

An interesting example at this juncture is designing and planning a shrine or a dargah for Jalaluddin al-Sayyid Muhammad Fadl P.P. Pokoya Thangal, a Sufi sheikh from the Qadiriyyah tariqah or fraternity. When the Sheikh passed away in 1992, a difference of opinion, especially among his followers, shortly arose as to whether to build a shrine over his grave or not. The opponents of the idea contended that it is not an Islamic custom to erect structures over graves as the Prophet Muhammad (pbuh) never did so and seems to have explicitly forbidden it.

However, the proponents argued that what the Prophet (pbuh) did and say is conditional, and to build shrines over extraordinary religious personalities, such as the Sheikh in question, purely in order to advance the cause of Islam and the spread of its message, is a totally different thing. It is even a praiseworthy undertaking. Eventually, the view to build a shrine prevailed and the next task was to find an architect. The search, however, did not last long. The succeeding leader of the Qadiriyyah tariqah, Sheikh al-Sayyid Mohammed Khaleel Thangal, chose Mr. Nazeer Khan who at that time was a relatively young and unproven, but passionate and promising, architect. The Sheikh says that he selected Mr. Nazeer Khan due to some inner and spiritual impetuses which amounted to something that could be dubbed a "supernatural inspiration". He had full faith in his judgment and knew that Mr. Nazeer Khan will be able to deliver that which he was entrusted with.

Upon the said request, and having been fully acquainted with the controversies that surrounded the decision to build a shrine, Mr. Nazeer Khan knew that he was up to a serious challenge. He was not happy that the purely religious project was shrouded in a dispute, as he believed that such projects should unite and not divide the people. He thus decided to make use of the proposed edifice and the way it will be designed and utilized to bring the controversy to an end. He wanted the building to bring the Muslims 
together, to be an agent of peace and harmony, rather than disagreement and disunity.

When the design was ready, subsequent to lengthy discussions with the leaders of the tariqah, it was presented to Sheikh al-Sayyid Mohammed Khaleel Thangal. The latter's comments simply were: "This is it. This is what I fundamentally wanted from the beginning, but was unable to put it into words. You (Mr. Nazeer Khan) did the job as if you have read my mind and soul."

Basically, what was special about the design and plan of the shrine was the way the grave of the deceased Sheikh was taken care of. In order to appease the advocates of building the shrine, Mr. Nazeer Khan created for them a wonderful and spacious structure at the centre of which stood a chamber. The chamber is one of a few meant for conducting various religious ceremonies and with various capacities in the shrine. In the middle of the central chamber sits a somewhat commanding cenotaph which, actually, is empty. And this exactly is what was meant to appease the opponents to the idea of building the shrine. The cenotaph only indicates the location of the grave which is well below in another separate and roomy chamber to which one goes via a special and secretive route.

The grave is rather simple, just like most other Muslim graves, and when visiting it, one feels that he visits directly the grave with no barriers or obstructions standing between him and the latter, just like in a graveyard. One furthermore gets a feeling and can witness with his own eyes that there was no serious tampering with the grave. Rather, the same was only well and ingeniously handled and shielded, retaining its original site and purpose.

Hence, the shrine is impalpably two-tiered, a lower tier with the grave and nothing else, and an upper tier with the cenotaph and all the facilities expected in a funerary complex. The shrine has multiple circulation systems as much indicating as facilitating its two-fold purpose. Effectively, everyone visiting the place finds what he needs. Everyone is busy with his own activities and emotions, with little or no time to worry about others and what they do and feel. This way, the building significantly toned down the controversy that preceded its conception and construction.

This penchant of Mr. Nazeer Khan for fostering inter-faith understanding and unity through architecture is being increasingly noticed and appreciated. For instance, a half-day session of an international seminar on inter-faith harmony and tolerance held in Kuala Lumpur from $3^{\text {rd }}$ to $8^{\text {th }}$ February 2014 was dedicated to Mr. Nazeer Khan's efforts and achievements. The seminar was coorganized by the International Islamic University
Malaysia, Ma'din Academy, Kerala, Department of National Unity (Prime Minister's Department, Malaysia), and OIC Today Magazine. Parallel to the seminar, Mr. Nazeer Khan also held a solo exhibition on housing in Kerala. The exhibition was organized by and held at the Kulliyyah (Faculty) of Architecture and Environmental Design, the International Islamic University Malaysia. It was visited by hundreds.

\section{Mr. Nazeer Khan's Architecture: Diversity in Unity}

Mr. Nazeer Khan is an architect, interior designer and landscape architect. His approach to architecture is all-in-one. There is no clearly dividing line between the three. When one talks to him, or studies his buildings, one cannot distinguish where one vocation ends and where the other one starts. If throughout ancient and medieval history most architectural designs and constructions were carried out by artisans, such as stonemasons and carpenters, rising to the role of master builder, then in a contemporary sense, Mr. Nazeer Khan could be described as a master architect whose ideas, which in the minutest details cover entire architectural processes from sheer concepts to the full use of buildings, are executed by tens of trusted contractors.

Mr. Nazeer Khan is a perfectionist. He is obsessed with what he does, and his obsession covers each and every aspect and phase of his projects. He meticulously supervises everyone: his assistants, contractors and supervisors, hopping from one site to another and from one town to another. His phone never stops ringing and he seems never to get tired. In view of that, smallest deviations from what has been previously conceived, planned and sketched are not tolerated. No tasks are allowed to be executed unprofessionally and imperfectly by anybody and at any stage. He is displeased with anything that does not meet extremely high standards that he had set. It is not thus rare that a worker or a contractor is recalled to re-do a job after he had "completed" it and had departed from a site.

Mr. Nazeer Khan gets upset even with some clients who fail to grasp the essence and logic behind his design ideas. He spends long hours patiently talking and trying to convince them, for it is not always easy to get people's sundry perspectives and outlooks aligned together. To him, mediocrity is a serious perfidy that as much hurts him as blights and scars a building of his. It is unclear which one of them, in reality, "suffers" 
more. To him, moreover, the worst architectural mediocrity is about inability to transport an impeccably conceived building spectacle from a world of ideas to a world of tangible realities. It is about rendering a supposed perfect building impaired and somewhat dysfunctional. It is a sheer failure, a betrayal. Thus, everyone involved with Mr. Nazeer Khan is kept on his toes, performing to the best of his ability and always looking over his shoulder.

To Mr. Nazeer Khan, architecture is synonymous with flawlessness, precision and proportion. It follows the rules and principles of the perfect universe designed and created by the Perfect Creator. It is a recognition, extension and augmentation of the faultless equilibrium that runs through the veins of total existence. By no means is it imitating, much less challenging or surpassing, the latter. Indeed, there can be no imitation or challenge between two completely different domains with different existential qualities and spheres of influence.

God is the greatest and best Creator. Everything else comes second. Everything else, furthermore, ought to humble itself and subdue its existence to the paradigms of God's revealed Word, mercy and grace. Architecture, it follows, is an act of at once humbleness, appreciation and veneration. Hence, to Mr. Nazeer Khan, practicing architecture denotes an opportunity to acknowledge and bring closer to the human grasp some of the greatest secrets of the universe.

Architecture, thus, in many ways is a microcosm of the quintessence of the universe whereby architects, builders, artists, as well as the users of buildings, enjoy the prospects of engendering genuinely intimate relationships with the truth and its copious expressions and ways. It goes without saying that the thrust of the job of talented architects and artists is to feel indebted to God for the gifts and, as a way of appreciation, to remain humble, accountable and committed to enabling the ordinary people to experience and value those ontological truths as embodied by the art and architecture realms. Being an architect, therefore, is at once a privilege and responsibility, definitely the latter outweighing the former. Architects are servants rather than masters.

True architects are the servants of the dignified purpose of their profession, as well as of the needs and anticipations of people. At the same time, they are visionaries on account of their exceptional abilities and flair, inspiring and guiding those around them and making their lives more exciting, delightful and consequential. Architecture, therefore, is not just a profession. It is a life to be lived delightfully and responsibly. Due to this actuality, Mr. Nazeer Khan admits to live under much stress wondering whether he is on the right track to meeting the terms of the mission he feels has been created for, or not. He divulges that at times he even cries as a result of the convergence of all those concerns which causes in him a mixture of feelings that fluctuates between despondency, humility and vulnerability, to comparative self-esteem and exhilaration.

Mr. Nazeer Khan's architectural style could be described as one exemplifying the canon of diversity in unity. It presumes that all buildings of his fully respect and adhere to those basic values and principles that are considered part of the basic shared framework of his architectural approach. At the same time, every building freely maintains its own distinct sub-ethos, refinement and taste which do not conflict with the shared core. Respect for the whole and respect for all is at the essence of this Mr. Nazeer Khan's approach. All his buildings are different, yet in essence virtually same, carrying the same spirit. The most recognizable principles and rules which constitute the core or the shared framework of his architectural style are proportion, symmetry, firmness, orderliness, crude aesthetics, veneer, ostentatious mass and scale. All Mr. Nazeer Khan's buildings are perfectly symmetrical and proportioned, strong, heavy, flashy and grandiose. As they increasingly dot the landscapes of the Kerala state, they are all the time more easily recognized as his signature architecture.

In order to translate his architectural philosophy into reality, Mr. Nazeer Khan employs a hybrid architectural language. He freely uses elements from Classical, Neo-Classical, Mughal, Colonial and, to a lesser extent, vernacular Kerala architecture. The most prominent component in all his buildings, however, is the pillar which he uses excessively as a structural, functional and decorative element. Mr. Nazeer Khan is in love with pillars. He never tires of explaining how they give his buildings an extra dimension insofar as accentuating their strength, longevity, splendor and flamboyance is concerned, be it on their exteriors or the interiors. The sheer quantity and sizes of his pillars render his buildings heavier, bulkier and more sophisticated than what actually they are. And to Mr. Nazeer Khan, that's exactly where the authentic beauty of his buildings lies. He wants his buildings to bear a resemblance to a big, strong, well-built, beautiful and resourceful human being. One gets an impression that in certain, especially residential, buildings he stops using pillars only when he runs out of spaces and opportunities to overuse them. As a 
result, Mr. Nazeer Khan, in his private circles, is fondly known as "Mr. Pillar Khan".

Most of Mr. Nazeer Khan's buildings incorporate ingredients from all the mentioned architectural schools and styles, some buildings more and others less. There is no building that faithfully follows a single style or school. This could be interpreted, first, as reflecting the growing globalized character of India and its people, in general, and Kerala and its own people, in particular. That India and its people aim for a dominant economic role on the world scene is obvious in each and every aspect of Indian culture and civilization, with architecture leading the way. The people want their architecture to reflect and spur their globalized economic aspirations and agendas. They want it to symbolize their modified and affluent lifestyles which in terms of the latter's impact and influence are anything but conventional, unimaginative or one-dimensional. To some, Kerala serves only as a base for their globalized economic functioning.

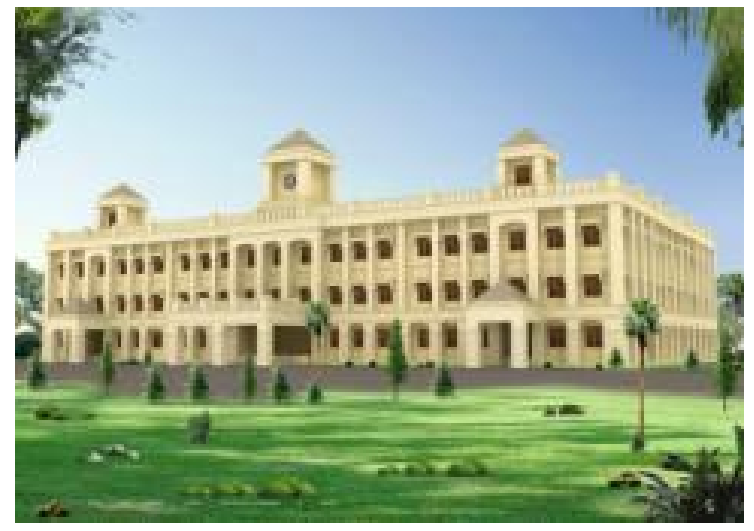

Figure 18. A proposed school and academy in Edappal, Malappuram, Kerala.

Second, Mr. Nazeer Khan cleverly resorts to the mentioned architectural schools and styles because most of them are regarded as truly international and ever-lasting styles. They never seem, and never will be, archaic and behind the times. For that reason do Mr. Nazeer Khan's buildings appear intrinsically amazing and likable, easily evoking positive sentiments and thoughts both in users and beholders. They are buildings with a universal appeal, for all seasons and tastes. At times, they can be truly captivating.

Due to the principles of diversity in unity and simplicity in complexity which his architecture personifies, plus his unique philosophy of architecture, Mr. Nazeer Khan and his architectural tendencies easily delude people into developing a number of misconceptions about them. One of those misconceptions is that Mr. Nazeer Khan caters only to rich clients, which is untrue -- although most of his clients are rich indeed - as explicated earlier. Mr. Nazeer Khan's clients are more diverse than what most people think.

Second, some people allege that Mr. Nazeer Khan's rich clients tend to completely isolate themselves from the rest of the less affluent people, having nothing or very little to do with them while enjoying all the luxuries of the world in their splendid dwellings, and the way Mr. Nazeer Khan designs those dwellings only promotes and facilitates such a life-style. This, too, is an overstatement.

Most of Mr. Nazeer Khan's clients, though rich, are hard-working, simple and very honest people. Their money, chiefly, is the result of their hard work, countless sacrifices and fair business dealings. Hence, if they are willing to invest a substantial chunk of their legitimate earnings into their houses, aiding thereby comfortable, sumptuous and exclusive life-styles for themselves, that is their own private matter. Nobody should really blame them for that, especially if they regularly and munificently settle all the financial dues that religion (Islam) imposes upon them in their capacity as wealthy individuals (this applies in particular to Mr. Nazeer Khan's Muslim clients). The subject rests entirely between them and God, All-Provider (Razzaq), who tests them with their riches and statuses in this world.

The questions of extravagance and vanity, two extremely abominable vices, could at times be misconstrued and placed in wrong contexts. Indeed, many clients are known in their respective towns and regions as helpful and generous people. Concerning many not only financial issues, people go to them first to seek help. Besides, some clients are enthusiastic about erecting and maintaining some public facilities, such as mosques. For example, Mr. K.V. Muhammad, for whom and whose family Mr. Nazeer Khan designed five houses, built a community mosque in the village of Edappal near his house.

Mr. Bashir Padiyath likewise built a mosque as well as a motel for the public, the latter being able to accommodate about 30 persons. There are two sections in the motel, one for men and the other for women. Both institutions, located near Mr. Bashir Padiyath's house and near a highway where they are most needed, are meant for the local population and will have several local employees who will be on Mr. Bashir Padiyath's payroll. Finally, not to be outdone in philanthropy by his clients, Mr. Nazeer Khan built a mosque from his own earnings for the community as well. 


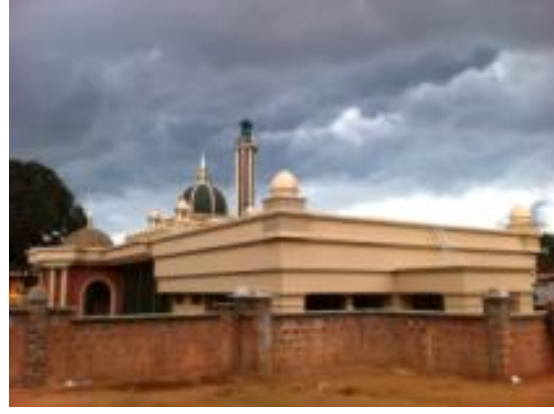

Figure 19. A shrine or a dargah for Jalaluddin al-Sayyid Muhammad Fadl P.P. Pokoya Thangal, a Sufi sheikh from the Qadiriyyah tariqah or fraternity in Calicut, Kerala.

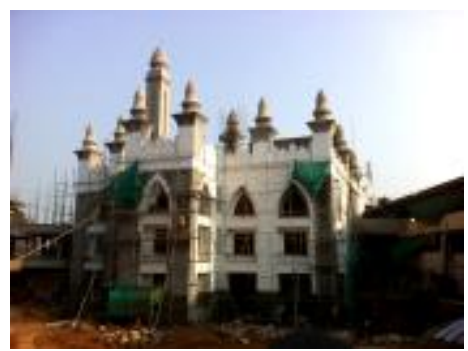

Figure 20. A mosque in Mattanurl Kannur, Kerala, under construction.

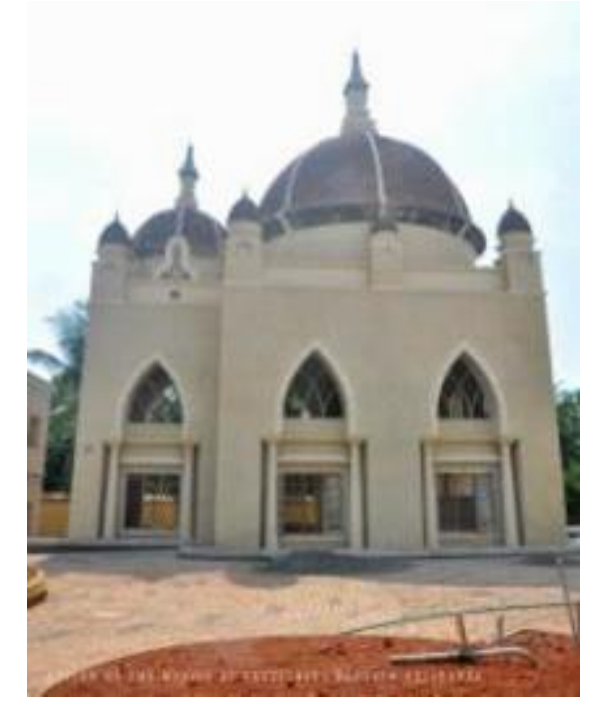

Figure 21. A mosque as part of Mr. Bashir Padiyath's residential complex in Vettichira, Malappuram, Kerala.

Third, there are those who contend that Mr. Nazeer Khan designs only private lofty houses where money is never an issue and where he and his untamed imagination can do anything they want. He is rather unable to exhibit his artistic and architectural aptitudes and to apply his professed architectural philosophy in other building types where budget constraints and some specific institutional requirements could become an issue posing a serious challenge to an architect and his resourcefulness and problem solving skills. This contention, in equal measure, is an exaggeration. It is unfair to excessively level this criticism against Mr. Nazeer Khan because, as we have already seen, not all clients of his are exceptionally well-off and so, the creation of their houses must be within the specified budget limits. Mr. Nazeer Khan lives with those constraints and still delivers. His ordinarily well-off clients are reasonably happy seeing good returns on their investments.

If his medium cost houses are somewhat more expensive than others of similar type, he defends the matter by saying that his houses are outstandingly quality houses and extra money means extra investment on quality and durability which invariably pays off. He is ready to challenge anyone to reason that such is not a shrewd investment. To Mr. Nazeer Khan, houses are built once in a lifetime. They must out-live their architects, builders and owners. They must perform and live up to expectations. They must always be assets, rather than liabilities, to their owners, in terms of their optimal function, usage and maintenance.

Hence, Mr. Nazeer Khan verbally guaranties that his houses (all buildings in general) will not show any serious signs of decaying during the first 15-20 years of their existence. During one of the field studies for writing this essay, one of his earlier houses after 21 years was undergoing some renovation work. When contacted, the house owner, Mr Hasan, said that the house needed only repainting and some general washing, which in fact did not even merit to be called renovation.

It goes without saying that the thing which Mr. Nazeer Khan dislikes most about the contemporary architecture in Kerala is that it is habitually asymmetrical, vulnerable, transient and unattractive. He regards the whole unfortunate issue as wasting people's money, time and opportunities. Mr. Nazeer Khan gleefully recalls how one of his houses whose construction cost was about 5 million rupees (about 86,000 USD) was estimated by a bank manager soon after its construction to cost about 15 million rupees (about 256,000 USD). Such were its panache and quality. At any rate, Mr. Nazeer Khan is open to designing any buildings with any budgets and for any type of clients. He guarantees that his architectural principles will under no circumstances be compromised.

Moreover, Mr. Nazeer Khan -- also as mentioned earlier -- designs many institutional buildings, big and small, where budgets are always tight and where an architect is guided primarily by copious requirements relating to the fixed roles and 
functions of those buildings. However, even there he duly delivers what is expected from him. It is true that such structures are devoid of most sumptuous and luxurious components that adorn most of Mr. Nazeer Khan's palatial houses, nonetheless, they are still intrinsically very pretty, stimulating and perfectly functional and efficient. They are still easily identifiable in the midst of other public and private surrounding buildings. They still carry Mr. Nazeer Khan's architectural signature. When asked and discussed with, members of the committees of some mosques, Hindu temples and churches, have nothing but lavish praise for Mr. Nazeer Khan and his work. Without hesitation, they recommend him to others whenever there is a chance to do so.

Finally, because he lives his architecture, to Mr. Nazeer Khan, his buildings are like living organisms. His affection for them is formed the moment he starts conceiving them in his mind. As the long architectural and then construction processes unfold, so that those abstract concepts can manifest themselves in the physical world, so does his love for his buildings intensify and grow, culminating with their completion. Mr. Nazeer Khan wants from the users of buildings to foster a similar emotional relationship with them. He wants people not only to mechanically use, but also feel affection for and cherish their buildings. Only then will architecture be able to contribute to people's happiness, and only then will people be able to exclaim that they have a good architecture which they can enjoy. The relationship between architecture and people is reciprocal, based as much on external and technical as on emotional and spiritual concerns.

Furthermore, to Mr. Nazeer Khan, houses that he designs and whose construction he oversees, are like his daughters. From the beginning till the end, he tenderly pampers, beautifies and nurtures them. They thus at all times must appear flawless and impeccable. Allowing any even minimal defects in the design and construction processes means taking away from the loveliness and gorgeousness of his daughters, which, therefore, cannot be tolerated. People live for the sake and future of their children. Their happiness is their parents' happiness.

Correspondingly, when a house is near its completion, Mr. Nazeer Khan sees it the same as a daughter approaching her adulthood, her perfection. Next, when a house is surrendered to its owner, such, instead of being the happiest, is the saddest moment for Mr. Nazeer Khan. That means that a daughter is being married off and she forever goes from her father's care and protection to her husband's. For Mr. Nazeer Khan, the swap is truly heart-breaking. Consequently, he never attends house-warming ceremonies which are ceremonies traditionally held within approximately one week or 10 days of moving into a new house. He cannot attend an occasion where a house (daughter) which heretofore was downright his and under his guardianship, and to whose grooming and development he devoted all his attention and energy, is officially and in his own presence transferred to somebody else's ownership and care.

He cannot attend an occasion, furthermore, where his house (daughter) is suddenly taken away from him, and where in a multitude of guests and visitors he feels as though he is just another guest. He cannot accept to play second fiddle to anybody when it comes to his own "creations". In other words, when his houses, as well as other buildings, are concerned, Mr. Nazeer Khan wants all or nothing at all. He seems irrepressible. He knows that this is quite a weird behavioral pattern, but he cannot help it.

As a matter of fact, he early in his career did once a mistake and attended a house-warming ceremony for a house which he had earlier designed. It was then that he vowed never to do it again. He still remembers the melancholy and pain he went through on that day. He promised never to subject himself to that emotional ordeal again. Even after house-warming ceremonies, Mr. Nazeer Khan feels so sad when he visits a house and when he must seek permission from its owner and inhabitants just to enter. He feels increasingly alienated from his inventions. This, too, is similar to a daughter who when she gets married lives with her husband in a separate housing unit. Visiting her is no longer all about her. It is about her and also about her husband. It is about a pattern of sharing which Mr. Nazeer Khan is not, and will never be, really ready for.

\section{Conclusion}

Mr. Nazeer Khan is a phenomenon worth studying. What he has done to the modern architectural landscape of the Kerala state - and still does - no other Indian architect has arguably ever done. His architecture is captivating -- sometimes to the point of being breathtaking -- astounding, intriguing, but also provocative - all at once. Perhaps, there is no architect in the whole of India who divides architectural opinions more than him. This led to the surfacing and cementing of several serious misconceptions about him and his architectural legacy, most of which have been dealt with in this essay. 
By and large, Mr. Nazeer Khan's architecture is both a product and epitome of Kerala Muslims' economic transformation, although the Kerala state's overall socio-economic and political stability and progress plays a notable role as well. One of the most fascinating aspects of Mr. Nazeer Khan's architecture is the way it promotes and facilitates inter-faith understanding and harmony for which the state of Kerala is so famous and from which all other Indian states can learn a lot. Further, his architecture faithfully applies the tenet of diversity in unity according to which all buildings fully adhere to those basic values and principles that are considered part of the basic shared framework of his architectural world-view. At the same time, every edifice freely maintains its own distinct sub-ethos, refinement and taste which do not belie the shared nucleus.

Nonetheless, in order to make his architecture appealing to even brother audiences and to increase his fan-base, Mr. Nazeer Khan needs to address more seriously the growing and intensifying trends in contemporary architecture circles, such as sustainability, eco-friendly buildings, and showing more appreciation and respect towards the merit of local traditions and their aesthetic expressive and symbolic value. It is true that Mr. Nazeer Khan is an admirer of Kerala's traditional architecture, mainly because it follows the omnipotent law of proportion and is commonsensical, yet he should display more readily a fondness for modernizing and reinvigorating the perpetual significance and worth of traditional architecture, and to keep searching for creative ways and means to gradually integrate the same into his both private and institutional buildings.

Also, when all is said and done, Mr. Nazeer Khan should make his architecture even more accessible to and affordable by ordinary people. This way, he will make way bigger his contributions to Kerala society, moving it a step closer to solving its mounting architectural predicaments. This, indeed, would be an immense challenge for Mr. Nazeer Khan to which, on account of his unprecedented talent and will-power, he can rise and triumph over - if he so wants and has time for.

\section{References}

[1] “Kerala Gulf Diaspora." [Online]. Available: http://en.wikipedia.org/wiki/Kerala_Gulf_di aspora. [Accessed: 11-May-2014].

[2] M. B. Mistry, "Kerala Muslims - Impacts of Gulf Remittances." [Online]. Available: http: / /islamicvoice.com/islamicvoice/kerala -muslims-impact-of-gulf-remittances. [Accessed: 11-May-2014].

[3] K.K.George and P. Sunaina, "Dynamics of Change in Kerala's Education System: The Socio-economic and Political Dimensions," in Kochi: Centre for Socio-economic \& Environmental Studies, 2005, pp. 5-13.

[4] "Islam and Muslims in India: Problems of Identity and Existence." [Online]. Available: http: / /andromeda.rutgers.edu/ rtavakol/en gineer/muslims.htm. [Accessed: 13-May2014].

[5] “Kerala People and Religions." [Online]. Available:

http://www.prokerala.com/kerala/religions. htm. [Accessed: 13-May-2014].

[6] S. Hassan, "Jama'at-i-Islami and the Muslim Reform Movement in Kerala." [Online]. Available:

http: //www.svabhinava.org/meccabenares/ YoginderSikand/SiddiqHassanKeralaJamaatframe.php. [Accessed: 13-May-2014].

[7] H. Randathani, "Mapilla Muslims," in Calicut: Other Books, 2007.

[8] M. Shokoohy, Muslim Architecture of South India. London: Routledge Curzon, 2003, pp. 137-210.

[9] H. Randathani, Mapilla Muslims. pp. 23-30.

[10] K. K. N. Kurup, "Evolution of Residential Architecture in Kerala," OIC Today, Business \& Investment Magazine (Special Pull-Out), Kuala Lumpur, p. 11, 2014.

[11] “Worship in Homes." [Online]. Available: http://www.asia.si.edu/pujaonline/puja/ho mes.html . [Accessed: 15-May-2014]. 